\title{
Recent Advances in Our Understanding of the Role of Meltwater in the Greenland Ice Sheet System
}

\author{
P. W. Nienow ${ }^{1}$ (D) A. J. Sole ${ }^{2}$ - D. A. Slater ${ }^{1}$ - T. R. Cowton ${ }^{3}$
}

Published online: 7 November 2017

(C) The Author(s) 2017. This article is an open access publication

\begin{abstract}
Purpose of the Review This review discusses the role that meltwater plays within the Greenland ice sheet system. The ice sheet's hydrology is important because it affects mass balance through its impact on meltwater runoff processes and ice dynamics. The review considers recent advances in our understanding of the storage and routing of water through the supraglacial, englacial, and subglacial components of the system and their implications for the ice sheet.

Recent Findings There have been dramatic increases in surface meltwater generation and runoff since the early 1990s, both due to increased air temperatures and decreasing surface albedo. Processes in the subglacial drainage system have similarities to valley glaciers and in a warming climate, the efficiency of meltwater routing to the ice sheet margin is likely to increase. The behaviour of the subglacial drainage system appears to limit the impact of increased surface melt on annual rates of ice motion, in sections of the ice sheet that terminate on land, while the large volumes of meltwater routed subglacially deliver significant volumes of sediment and nutrients to downstream ecosystems.

Summary Considerable advances have been made recently in our understanding of Greenland ice sheet hydrology and its wider influences. Nevertheless, critical gaps persist both in
\end{abstract}

This article is part of the Topical Collection on Glaciology and Climate Change

P. W. Nienow

Peter.Nienow@ed.ac.uk

1 University of Edinburgh, Edinburgh, UK

2 University of Sheffield, Sheffield, UK

3 University of St Andrews, St Andrews, UK our understanding of hydrology-dynamics coupling, notably at tidewater glaciers, and in runoff processes which ensure that projecting Greenland's future mass balance remains challenging.

Keywords Greenland ice sheet · Ice sheet hydrology · Ice dynamics · Tidewater glaciers $\cdot$ Sediment and solute fluxes . Ice sheet erosion

\section{Introduction}

The generation, routing, storage and evacuation of meltwater represents a critical component in the Greenlandic ice sheet (GrlS) system [1]. The system is composed of three main components concerning the routing of waters across the surface of the ice sheet (supraglacial), internally through the ice sheet (englacial) and beneath the ice sheet at the ice bed interface (subglacial). Each component displays distinct spatial and temporal variations at a variety of scales with important implications for wider ice sheet processes. The efficiency of the routing of surface-generated meltwater through all components of the system has implications for ice sheet mass balance and thus sea level since longer term storage, or refreezing of meltwater, delays its loss from the ice sheet. The ability or otherwise of surface meltwaters to access the subglacial drainage system is dependent on the volume of surface meltwater generated, the temperature and stress regime within the ice (and thus crevasse distribution) and the structure of the englacial system $[1,2]$. The nature of subsequent meltwater flow through the subglacial drainage system has implications for glacier motion (via basal sliding), glacier erosion (through the generation and mobilisation of subglacial sediments) and the hydrochemistry of glacial runoff which influences downstream terrestrial and ocean ecosystems. It is therefore of critical importance to 
understand the role of meltwater in the ice sheet system and how this will change in the future.

The importance of meltwater to glacial systems, and downstream regions affected by the meltwater, has long been recognised and comprehensive research has investigated temperate alpine glacier hydrology $[2,3]$ and more recently High Arctic polythermal glacier hydrology [4]. Prior to the twenty-first century however, the hydrology of the GrIS had received little attention, with the exception of reports in the Rapport Grønlands Geologiske Undersøgelse [5] which remain largely unused by the research community, and studies at Jakobshavn Isbrae [6]. This perhaps reflected in part the view that ice sheets were stable over millennial timescales and that surface meltwaters would not penetrate through the ice to the glacier bed due both to the cold (i.e. below pressure melting point) impermeable surface ice and the considerable ice thicknesses. This representation of the hydrology of the GrIS, and its importance to wider ice sheet processes, has been revolutionised since 2000 as a result of some pioneering papers and a consequent dramatic expansion of the research area.

One of the first indications that surface meltwaters could impact GrIS dynamics (and thus by inference access the ice sheet bed) was from satellite observations of a period of (inferred) supraglacial lake drainage and a consequent speed-up in ice motion [7]. This was followed by observations of a close correspondence between surface melt rates and ice acceleration at a site where the ice was over $1 \mathrm{~km}$ thick [8]; the inference again was that surface meltwaters were accessing the ice bed interface, thereby perturbing the subglacial water pressure and enhancing ice motion through basal sliding. Confirmation of the unequivocal link between surface meltwater drainage and ice dynamic response came from observations of ice acceleration and surface uplift following the rapid drainage of two large supraglacial lakes in west Greenland through ice $980 \mathrm{~m}$ thick [9]. The realisation of this direct hydro-dynamic ice sheet coupling, and the potential implications for a mechanism by which the ice sheet might respond rapidly to climate warming, has seen a proliferation of research into the hydrology of the GrIS. This activity is reflected in recent detailed review papers which consider GrIS hydrology $[1,10]$ and the modelling of water flow under ice sheets [11]. These papers (each with $>220$ references) cover the topic thoroughly, so this paper does not aim to replicate these reviews. Instead, we focus on the most significant research developments of the last 5 years, discuss their wider significance and consider the most pressing debates and research gaps with respect to GrIS hydrology. In advance of these more discursive issues, we first consider the current state of knowledge regarding the meltwater processes operating in the supraglacial, englacial and subglacial environments.

\section{Supraglacial Meltwater Processes}

The volume of meltwater generated at the GrIS surface has increased dramatically in recent years due to an expansion of ice sheet melt extent [12] and enhanced local melt rates [13] the result of: warmer air temperatures [14]; decreasing albedo [15] due to a darkening ice surface caused by increased aeolian dust [16], exposure of dirty Holocene ice [17], increased biota and cryoconite [18] and changing snowpack structure and moisture content [19]; decreased meltwater retention capacity in the firn [20]; and changing radiation budgets associated with synoptically driven changes in cloud cover [21,22]. The impact of this enhanced melt is reflected in the GrIS's increasingly negative balance, contributing $\sim 0.5 \mathrm{~mm}$ year to sea level between 1991 and 2015, at an accelerating rate of loss of $\sim 17 \mathrm{Gt} \mathrm{year}^{-2}$ [23•]. In recent years, approximately $60 \%$ of this loss has resulted from increased summer melt and associated runoff $[23 \bullet, 24]$. The net effect of this accelerating melt is the presence of more mobile water at the ice sheet surface which can subsequently experience several fates: (i) percolation and refreezing locally in the underlying snowpack or firn; (ii) percolation and storage in firn aquifers; (iii) lateral flow through the snowpack and firn or across the ice surface as a film or in channels. If this last path is taken, the water may then: (iv) become ponded in supraglacial depressions (in lakes or crevasses); (v) be routed to open moulins or crevasses and drain englacially into the ice sheet; or (vi) drain over the surface until routed off the edge of the ice sheet. The nature of the supraglacial routing will depend on the characteristics of the supraglacial surface [25] with slower percolation and Darcian flow typical of areas covered by snow and firn and more rapid routing across snow free areas of impermeable ice.

While the basic processes associated with meltwater percolation through the snowpack and firn, with the potential for refreezing, have been extensively studied [25-27], major advances in recent years have resulted from extensive groundbased field campaigns in the percolation zone of the GrIS. The potential of porous firn to store refrozen meltwater, and thereby delay meltwater runoff, has been highlighted as a mechanism by which sea level rise could be considerably buffered for decades in a warming climate [28]. Subsequent work, collecting repeat shallow firn cores along a transect ranging from 1840 to $2361 \mathrm{~m}$ elevation in west Greenland, suggests however that recent extreme melt years are negating the ability of the snowpack and firn to buffer enhanced runoff [29•]. A series of warm summers, including the exceptional melt years of 2010 and 2012, have modified the firn structure such that at higher elevations (above $\sim 1900 \mathrm{~m}$ ), the firn has experienced substantial densification, while at lower elevations, the formation of laterally extensive near-surface ice layers has almost certainly reduced the potential for percolation and storage in the deep firn. As a result, meltwater is instead draining more 
rapidly from the ice sheet surface [20], thereby promoting earlier ice sheet mass loss from higher elevations in response to rising temperatures.

An additional complexity, regarding the role of the firn in controlling meltwater runoff, concerns the potential for considerable water storage in extensive perennial firn aquifers, as observed across part of the South-East GrIS [30••]. Here, a combination of ground and airborne radar, shallow firn cores and modelling indicate that the top of the firn aquifer ranges in depth from 5 to $50 \mathrm{~m}$ from the ice sheet surface, covers up to $\sim 70,000 \mathrm{~km}^{2}$ and stores up to $140 \mathrm{~km}^{3}$ of water; the aquifer thus represents a previously unknown yet significant mode of meltwater storage. The subsequent fate of the aquifer waters (refreezing or runoff) remains unclear [31] although modelling suggests that the potential water flux provided by the aquifer is sufficient to induce hydrofracture to the bed via crevasses, thereby providing a mechanism for both aquifer drainage and a potential impact on ice dynamics [32].

While storage of waters within the firn aquifer has only recently been revealed, the visible ponding of water in extensive supraglacial lakes has been known for decades [33, 34] and their large size and the ready availability of satellite data has seen a marked increase in research on supraglacial lake development and drainage. These data reveal that lakes form seasonally in depressions in both the ablation and lower accumulation zones of the ice sheet [35], with their locations controlled by the underlying subglacial topography [36] or basal friction [37] thereby ensuring that they typically reform in the same location each year given sufficient surface meltwater.

During the course of each melt season, the lakes first form at lower elevations, and the majority subsequently drain, with these processes extending to higher elevations as air temperatures rise and the melt season progresses [38-40]. The lakes can either drain rapidly by hydrofracture $[9,41,42]$ or more slowly by overtopping their topographic lip and draining supraglacially downstream [43-45]; a 5-year study of $\sim 2000$ Greenland-wide supraglacial lakes estimated that $13 \%$ of the lakes were 'fast-draining' $(<2$ days) [35], while a 10-year catchment-based study of $\sim 200$ lakes estimated that $28 \%$ of the lakes drained 'rapidly' ( $<4$ days) [38]. Rapid lake drainage results in large volumes of water entering the subglacial drainage system in a few hours with rates of 8700 and $3300 \mathrm{~m}^{3} \mathrm{~s}^{-1}$ recorded $[9,41]$. In order for surface lakes to drain, an appropriate stress regime in the ice is required with existing crevasses, which can then be exploited and expanded by ponded surface waters draining englacially via hydrofracture [46-48]. There is as yet no evidence however to support the idea of a unifying critical lake volume or depthdependent drainage threshold [38].

While some meltwater is stored in supraglacial lakes, once the winter snowpack has been removed, the majority of surface meltwater is transported across the ice sheet surface in efficient supraglacial stream networks prior to delivery to crevasses and moulins [5, 44, 49] (near vertical pipes [50] that drain water through the ice). An extensive study across a $6812 \mathrm{~km}^{2}$ area of the SW Greenland ice sheet between $\sim 1000-1500$ m elevation [49], encompassing 523 channels that terminated in moulins, obtained mean moulin discharge of $3.15 \mathrm{~m}^{3} \mathrm{~s}^{-1}$ (with a maximum of $17.7 \mathrm{~m}^{3} \mathrm{~s}^{-1}$ ). Furthermore, the study demonstrated that the efficient routing of water into the extensive supraglacial channel network ensured a minimal delay between meltwater generation and its delivery to the englacial system.

\section{Englacial Meltwater Processes}

Supraglacial meltwater will enter a glacier or ice sheet and flow englacially where it encounters or can create a permeable pathway. In temperate glaciers, these pathways provide either rapid routing of meltwater through the localised macroporosity provided by moulins and crevasses or slower drainage via the microporosity provided by the permeable vein structure within the ice [2]. Within the GrIS, the 'cold' nature of the solid ice ensures that percolation through the englacial vein structure is dramatically reduced and the ice is thus effectively impermeable except at the macroscale. As a result, meltwaters will only drain into the ice via crevasses or moulins.

The presence of crevasses is dependent on the stress regime within the ice, and recent modelling studies in Greenland have used the von Mises yield criterion [44, 46] to predict areas where crevassing will occur. Where crevasses intersect surface drainage, meltwater ponding in the crevasse will occur establishing the potential for hydrofracture to propagate the crevasse to the glacier bed [48]. Once a connection is made at the bed, surface meltwaters can flow englacially down the crevasse or moulin which has now been created. Frictional heat dissipation in the flowing water will subsequently keep the moulin open as long as the melt rate exceeds the rate of ice creep closure [2]. As a result, larger volumes of water are required to both initiate and maintain moulins at higher elevations where ice thicknesses and thus creep closure rates are greater. Lake hydrofracture therefore appears to be the dominant process initiating moulins at higher elevations on the ice sheet [44].

Due to a combination of decreasing meltwater availability and a reduction in crevassing due to the stress regime, the potential for hydrofracture and thus the density of moulins decreases with elevation $[44,51,52]$. In west Greenland, Poinar et al. [52] observed a moulin density of $0.02 \mathrm{~km}^{-2}$ between 1500- and 1600-m elevations which compared with $12 \mathrm{~km}^{-2}$ at lower $(0-1100 \mathrm{~m})$ elevations [51]. This reduction in moulin density ensures that at high elevations, meltwaters are often transported considerable distances from the source of 
meltwater generation to the point of input to the englacial drainage system [34].

Determining whether there is an upper limit beyond which meltwater can no longer penetrate from the surface to the bed of the ice sheet is important due to the potential impact of surface meltwater inputs on ice dynamics. In a warming climate, additional meltwater will be generated at higher elevations, and the inland migration of melt extent, lake formation and rising equilibrium line altitude have already been observed in recent decades $[39,53]$. Nevertheless, an investigation of strain rates in a west Greenland catchment predicted that new hydrofractures at high elevations are unlikely [52•] such that most high elevation $(>1600 \mathrm{~m}$ ) melt will be routed over the ice sheet surface and delivered to existing moulins at lower elevations; a finding supported by research suggesting that surface-to-bed connections via hydrofracture of lakes will continue to be limited at higher elevations [47]. It is important to note however that both these studies were undertaken in regions of the ice sheet with slow flow $\left(\sim 100 \mathrm{~m} \mathrm{year}^{-1}\right)$ and the stress regime at higher elevations, in faster flowing tidewater glacier catchments, could encourage higher and expanding surface-to-bed connections [54].

The precise morphology of moulins and surface-to-bed connections remains unclear. It seems likely however that these features are largely vertical through inference from a number of lines of evidence including (i) field-based ice-penetrating radar studies [50], (ii) surface uplift in close proximity to the lake that occurs immediately following rapid lake drainage events [9, 41, 55] and (iii) the expectation that the physics of hydrofracture will most efficiently drive crevasses vertically from the ice surface to the bed [48]. Furthermore, it seems likely that moulins will be hydraulically efficient once formed, with turbulent and high velocity flow, in order to generate the high frictional melt rates required to prevent the closure of the englacial channels (or 'pipes') at depth where ice is often $>500 \mathrm{~m}$ thick. This inference is supported by the fact that once open, moulins continue to efficiently drain large supraglacial streams with discharges commonly upwards of $5 \mathrm{~m}^{3} \mathrm{~s}^{-1}[9,49]$; repeated surface ponding would be more commonplace if moulins did not maintain efficient drainage following their initial opening each melt season.

\section{Subglacial Meltwater Processes}

Meltwater at the ice bed interface can originate either from supraglacial inputs delivered via the englacial system or from locally sourced basal meltwaters derived from geothermal or frictional melting. During the melt season, subglacial drainage will be dominated by supraglacial inputs in areas where surface meltwaters can access the bed, while basal meltwaters will dominate in winter and in areas that are isolated from surface inputs. Parts of the interior of the ice sheet are frozen to the bed, and thus have no subglacial drainage. While the precise extent of the area of the ice bed interface which is frozen remains unclear [56], in large part due to uncertainty regarding the geothermal heat flux, modelling from Southwest Greenland suggests that ice at the bed down glacier of the 2000-m ice sheet surface contour would be expected to be at the pressure melting point $[52 \bullet, 57]$.

In most circumstances, the basal hydrological system of the GrIS will be pressurised, with meltwater routed down the steepest hydraulic potential gradient. Under an idealised scenario in which all meltwater is at the local overburden pressure, the hydraulic potential field is controlled primarily by the ice surface topography, with basal topography playing a secondary role [2]. However, subglacial water pressure varies spatially and temporally due to heterogeneities in the drainage system structure and water delivery, causing hydraulic gradients to evolve and even reverse on timescales ranging from diurnal to seasonal [58••, 59]. Under certain topographic conditions, meltwaters may also be stored in subglacial lakes [60], temporally delaying the routing of waters to the ice sheet margin if the lakes are connected to the wider ice sheet subglacial drainage system.

Several theoretical models of the likely hydraulic structure of subglacial drainage systems have been proposed and all have some support from field evidence, although primarily at valley glaciers $[2,4]$. These drainage systems can be classified in to two broad categories: hydraulically 'efficient' (or 'channelised') and 'inefficient' (or 'distributed') systems, which are distinguished by the geometry of their passageways and thus the ease of water flow. Whether the water follows efficient or inefficient drainage routes will depend, among other things, on the bed topography, the nature and permeability of the bed materials, the thickness, temperature, and surface gradient of the overlying ice, the rate of ice flow and the rate and distribution of meltwater delivery to the bed [2].

In order for hydraulically efficient subglacial channels to exist, channel expansion due to frictional melting by flowing water must equal or exceed the creep closure of the surrounding ice [2]. All else being equal, higher meltwater fluxes and steeper hydraulic gradients will enhance frictional melt, favouring the development of efficient channels, while warmer (and therefore softer), thicker, or steeper-surfaced ice will cause more rapid creep, discouraging channel formation. Numerous studies in valley glacier systems have demonstrated a seasonal evolution in subglacial drainage system structure, driven by the seasonal evolution in surface melt. Early melt season drainage is thought to occur primarily via a distributed system with low hydraulic efficiency [2]. As surface melting intensifies, inputs to the subglacial drainage system cause elements of the distributed system to become unstable [61], resulting in the development of channels which evolve into an arborescent system which expands up glacier as surface-to-bed connections are established [2]. Conversely, 
as surface meltwater fluxes to the bed reduce towards the end of the summer, ice deformation causes the gradual closure of channelised drainage structures.

As elsewhere, investigating Greenland's subglacial hydrology is challenging due to issues of accessibility. Recent advances have primarily been driven by water tracing and borehole studies, monitoring the characteristics of emergent subglacial meltwater properties, theoretical modelling studies and inferences based on the surface dynamics determined from field-based or remote-sensing methods.

Tracer studies, using fluorescent dyes and $\mathrm{SF}_{6}$ (Sulphur Hexafluoride), reveal a seasonal evolution from inefficient to efficient drainage as surface melt increases, as in alpine systems $[62,63]$. Efficient drainage pathways are demonstrated by the high throughflow velocities $\left(\sim 1-1.5 \mathrm{~m} \mathrm{~s}^{-1}\right)$ of the traced waters and the limited dispersion of the tracers, both indicative of channelised flow, at distances up to $\sim 40 \mathrm{~km}$ inland and beneath $\sim 1000$-m thick ice [62]. Furthermore, the rapid transmission of large pulses of meltwater from the surface to the ice sheet margin, via the englacial and subglacial drainage systems, is also indicative of efficient drainage with very limited storage [49]. Seasonal observations of meltwater properties from a proglacial river in west Greenland are also indicative of the up glacier expansion of an increasingly efficient subglacial drainage system to distances $>50 \mathrm{~km}$ from the ice sheet margin [64].

The inland limit of efficient subglacial drainage, such as channels, remains unclear [65]. A tracer test from a moulin $\sim 57 \mathrm{~km}$ inland, where ice is $\sim 1200 \mathrm{~m}$ thick, indicated subglacial routing through less efficient drainage [62]. Other observations however suggest that efficient drainage can reach well in to the interior of the ice sheet to distances extending to $80 \mathrm{~km}$; observations during rapid supraglacial lake drainage events reveal dramatic horizontal and vertical acceleration of the ice as vast volumes of water drain to the bed $[9,41,55]$. The subsequent rapid $(\sim 24 \mathrm{~h})$ drop in vertical ice bed separation suggests that the water has been evacuated down-glacier quickly and efficiently. That this evacuation is likely the result of efficient subglacial drainage is further supported by horizontal ice flow velocities which quickly drop to similar or below those observed prior to the establishment of surface to bed hydraulic connection, despite continuously high supraglacial melt rates $[9,55]$. If the drainage system had remained inefficient following lake drainage, velocity enhancement relative to predrainage values would instead be expected [61, 66]. Nevertheless, the precise form(s) of these efficient drainage systems remains unclear with the rapid evacuation at the bed of supraglacially draining lake waters being proposed via both a transient subglacial turbulent distributed sheet [67] as well as drainage via hydraulically efficient channels [64].

Detailed subglacial water pressure measurements would appear to further confirm the similarities between alpine glacier and GrIS hydrology. At a site $\sim 20 \mathrm{~km}$ from the ice sheet margin, Andrews et al. $[58 \bullet \bullet])$ drilled boreholes through $\sim 600-\mathrm{m}$ ice to the bed and monitored water pressure in both the boreholes and in nearby $(\sim 0.3-1.6 \mathrm{~km}$ distant $)$ moulins during the second half of the 2011 and 2012 melt seasons. Their results suggest that the moulins directly fed an efficient channelised component of the drainage system while the boreholes, by contrast, monitored a hydraulically inefficient drainage system. This juxtaposition of efficient subglacial channels draining waters between hydraulically inefficient areas of the bed mimics conditions observed in alpine glacial systems [59, 68]. A contrary conclusion was reached by a study which found minimal subglacial water pressure variations in a borehole $34 \mathrm{~km}$ from the ice margin, under ice $\sim 830 \mathrm{~m}$ thick [69], which the authors interpreted as indicative of a lack of channelised drainage extending inland beneath deep ice. However, the spatial 'footprint' of subglacial channels would likely be very small, given both the low density of moulins at higher elevations, and observations of almost invariant water pressures in boreholes located within $<100 \mathrm{~m}$ of a subglacial channel [59]. As such, the likelihood of drilling a borehole through thick ice into a well-connected subglacial channel, as evidenced also by Andrews et al. [58••], is low.

Numerical modelling using two-dimensional multi-element drainage systems largely support the evidence for the development of efficient subglacial drainage [11]. These models, driven by seasonally varying supraglacial meltwater inputs, demonstrate a seasonal evolution in subglacial hydrology from distributed to channelised drainage [70-72] which build on the earlier theoretical work of Kamb [61]. There are however disparities between model results $[65,70]$ and evidence from field data $[55,62]$ in terms of the rates at which (or even whether) channels can form and the distance to which they will extend inland from the ice sheet margin.

As noted above, the precise structure of both inefficient and efficient drainage configurations remains unclear. Recent evidence [73-75] suggests that parts of the ice sheet are underlain by subglacial sediments. In such areas, efficient drainage where it exists is likely to be characterised by channels (or 'canals' [2]) incised both down in to the sediments as well as up into the ice, while inefficient drainage may occur via Darcian flow through the sediments [2]. Bougamont et al. [76] used an ice flow model incorporating a deformable sediment bed to show that observed temporal variations in ice flow could be explained by changes in the strength of subglacial sediment due to seasonal influxes of surface-derived meltwaters; three $\sim 2-\mathrm{km}$ long seismic profiles from south-west GrIS [75] also suggest that ice flow velocity scales with local subglacial sediment strength (but also with surface meltwater input). Nevertheless, there is as yet no empirical evidence for pervasive subglacial sediment cover [77, 78], in particular beneath the slower flowing land-terminating sections of the ice sheet, so the importance of associated ice dynamical impacts remains unknown. 
It should be noted that the majority of the investigations of subglacial hydrology (and dynamics coupling) have been undertaken at land-terminating margins of the GrIS in west Greenland. The extent to which these studies are applicable to marine-terminating ('tidewater') glacier systems remains unclear and is considered further in the next section.

\section{Wider Implications of Meltwater in the Greenland Ice Sheet System}

As noted in the introduction, the nature of the hydrological system has important implications for processes acting throughout the GrIS and around its margins. These are now considered with respect to ice dynamics, ice sheet erosion, downstream ecosystems and tidewater glaciers.

\section{The Greenland Ice sheet's Dynamic Response to Meltwater Inputs}

Numerous studies in Greenland have revealed the intimate link between surface melt and ice dynamics, whereby surface meltwater reaching the bed perturbs water pressure at the ice bed interface and thus causes a change in ice motion $[8,45$, $55,79]$; the fundamental link being that an increase in basal water pressure causes an increase in ice bed separation (i.e. a degree of floatation), a reduction in the local ice bed friction and the overlying ice therefore accelerates. These studies broadly reveal an initial acceleration in ice motion as surface meltwaters first gain access to the ice sheet bed each melt season and encounter a hydraulically inefficient subglacial drainage system [80, 81]. As the efficiency of the subglacial drainage system increases, the associated drop in subglacial water pressure results in a decrease in ice velocity $[55,80]$ although an efficient drainage system can continue to be overwhelmed, and thus overpressurised, by increasing surface melt during the rising limb of the seasonal runoff curve [63]. It is clear that the broad velocity decrease is not only the result of the establishment of efficient subglacial drainage [62] but also through the increasing capacity (and thus lower water pressure) within the extensive distributed system [58••, 82, 83•]. The characteristic evolution of initial acceleration followed by gradual deceleration occurs later at sites increasingly distal from the ice sheet margin, in response to the later onset of meltwater runoff at higher elevations. Any rapid changes in meltwater flux into the drainage system caused either by lake drainage events $[8,81]$, sudden increases in surface melt rate [84], or rainfall [85] may overpressurise the system and cause ice acceleration even when the drainage system is already efficient [63]. At the cessation of summer surface melting, the ice sheet slows to an annual minimum $[8,86,87]$ prior to a steady increase in motion overwinter, the latter presumably the result of basal melt repressurising the distributed subglacial drainage system in the absence of efficient channels that have been closed by ice deformation.

While short-term ice sheet motion is clearly responsive to changing melt rates and hydrology, from a broader perspective, the most important timescale to consider is whether increased melt rates make the ice sheet flow faster on an annual basis. In other words, will the ice sheet accelerate in a warming climate, in response to increased meltwater inputs? If so, this could lead to a positive feedback between warming and ice loss, due to the more rapid transfer of ice to lower, and thus warmer, elevations [8]. While increased surface melt can lead to higher average ice motion during some or all of the melt season, as the drainage system is repeatedly forced to accommodate greater volumes of meltwater [8, 86, 87], numerous studies have shown that increased melt does not enhance ice motion on annual timescales [79, 87, 88•, 89-91]. This is due to both the seasonal evolution in the efficiency of the subglacial drainage system which ensures that ice motion does not scale with melt [61], and potentially of greater importance, the role of water pressure in the more extensive distributed component of the subglacial drainage system [83•] which may be decreasing through time [90 • $]$. Between 1985 and 1994 and 2007 and 2014, Tedstone et al. [90*0] observed a $12 \%$ decrease in mean annual ice velocity across an $8000 \mathrm{~km}^{2}$ land-terminating area of the ice sheet, extending to $\sim 1200 \mathrm{~m}$ elevation, at the same time as melt rates increased by $\sim 50 \%$. They argued that the decrease in velocity is likely the result of the seasonal formation of larger and more frequent subglacial channels extending further in to the ice sheet due to increased surface melting. If these large channels act as low pressure arteries for meltwater drainage [58・•], they could act to decrease the water pressure in the surrounding distributed drainage systems, reducing ice velocities across large areas of ice sheet [83•].

Contrasting results are observed at the highest elevation areas of the ice sheet where a seasonal dynamic response to surface melt is still detected. Doyle et al. [92] observed a small $(2.2 \%)$ increase in ice motion, from 51.78 to $52.92 \mathrm{~m} \mathrm{year}^{-1}$ between a cooler (2009) and warmer (2012) year at a site $1840 \mathrm{~m}$ above sea level and $140 \mathrm{~km}$ from the ice sheet margin. This suggests that in regions where the ice is extremely thick (> $1500 \mathrm{~m}$ ), and basal water flux sufficiently low, efficient subglacial drainage may not become established, allowing melt and ice motion to scale positively. Observations from this zone are however limited, and so the significance of these findings for the wider dynamics remains unclear.

Modelling studies report contrasting behaviour in their predictions of the coupling of hydrology and dynamics in a warming world. While some models are able to simulate key aspects of the coupled seasonal hydrological and ice dynamics cycles (e.g. early season ice flow acceleration, subsequent reduced sensitivity to further meltwater inputs, and an end- 
of-season deceleration $[70,83 \bullet])$, on annual and longer timescales, modelling studies have found that increased surface melt leads to a net increase in ice flow in land-terminating catchments $[76,93]$. This contrasts with observations suggesting a net reduction in ice flow under increased surface melt $[88 \bullet, 90 \bullet \cdot$. Models do not therefore currently capture all of the relevant feedbacks between runoff and ice dynamics that are needed to predict long-term trends in ice sheet flow [88•].

\section{Erosion and Ice Sheet Hydrology}

The efficacy of glacial erosion is evident in numerous spectacular glaciated landscapes, including around the margins of Greenland, and through studies which reveal high rates of erosion (1-100 $\mathrm{mm}$ year $^{-1}$ ) across a range of glaciated environments [94]. Investigations of fjord sediment deposits in east Greenland led to the assertion that the GrIS must be characterised by very low $\left(\sim 0.01 \mathrm{~mm}^{-1}\right.$ year $\left.^{-1}\right)$ erosion rates [95]. However, two recent studies from west Greenland report much higher rates of erosion: $\sim 5 \mathrm{~mm}$ year ${ }^{-1}$, derived from sediment flux calculations from a large ice sheet catchment [96] and 1-1.8 $\mathrm{mm}_{\text {year }}{ }^{-1}$ from cosmogenic dating of exposed glaciated bedrock [97]. Cowton et al. [96] argued that large volumes of meltwater accessing the glacier bed, in conjunction with fast hydraulically competent (in terms of sediment transport) drainage routing, large ice thicknesses $(100->1000 \mathrm{~m})$ and rapid motion $\left(\sim 100 \mathrm{~m} \mathrm{year}^{-1}\right)$ provide the ideal conditions for both generating and evacuating large volumes of subglacial sediment [98]. Some subsequent studies [76] have argued that these high erosion rates must be indicative of the subglacial drainage evacuating readily mobilised layers of stored subglacial till, as opposed to freshly generated products of erosion. However, given that meltwater volumes, ice thicknesses and rates of ice (basal) motion are typically at least an order of magnitude greater in Greenlandic as opposed to alpine glacial catchments, there seems little reason not to expect their erosion rates to at least be comparable. Furthermore, an extensive network of 32 boreholes revealed hard subglacial bed conditions [78] while airborne radar surveys observe erosional subglacial landscapes [77] that mimic the exposed proglacial landscape characterised by scoured bedrock surfaces [99]; these findings point towards the ability of the ice sheet to effectively erode the underlying bedrock, as evidenced by the bedrock erosion estimates (1$1.8 \mathrm{~mm} \mathrm{year}^{-1}$ ) of Young et al. [97].

\section{Downstream Nutrient Fluxes and Ecosystems}

Where the runoff characteristics of subglacial meltwaters draining from the GrIS are monitored, it is clear that the waters have high sediment $[96,98,100]$ and solute $[101,102,103 \bullet$,
104] concentrations, primarily acquired during passage along the ice bed interface. These meltwaters therefore have the potential to provide significant quantities of nutrients to downstream terrestrial and marine ecosystems. Furthermore, meltwater nutrient fluxes are higher in years with higher runoff, suggesting that ice sheet-derived nutrients may become increasingly important if Arctic warming continues [103•]. These nutrients are classified into particulate and dissolved parts, with the GrIS typically exporting a greater proportion of particulate nutrients [103•]; however, these tend to be less bioavailable (i.e. useable for metabolic purposes by microorganisms) than the dissolved equivalents. In addition, of the nutrients critical to primary productivity in Greenlandic ocean waters, only dissolved iron and silicate are present in ice sheet sources in sufficient concentrations to significantly impact Greenlandic coastal productivity [105]. As a result, despite evidence that GrIS runoff contains significant concentrations of bioavailable nutrients, it remains uncertain whether projected increases in runoff will impact the primary productivity of Greenlandic ocean waters $[105,106]$.

\section{The Influence of Hydrology on Marine Terminating ('Tidewater') Glaciers}

While the broad characteristics of supraglacial and englacial meltwater processes discussed above are likely similar at tidewater glaciers, little is known of these glaciers' subglacial hydrology, due primarily to the extreme difficulty of undertaking traditional methods of hydrological investigation at such fast-flowing, marine terminating calving glaciers. Furthermore, inferring the subglacial hydrology based on characteristics of ice motion is complicated by the multitude of other factors controlling tidewater glacier flow dynamics including, for example, variability in terminus position [107], buttressing by sea ice/ice mélange [108] and tidal variations [109]. It is therefore unclear whether knowledge of subglacial hydrology at land-terminating margins may be applied to tidewater glaciers.

The two systems contrast principally in characteristic ice velocity $\left(\sim 100 \mathrm{~m} \mathrm{year}^{-1}\right.$ at land terminating glaciers vs. $>1000 \mathrm{~m} \mathrm{year}^{-1}$ at tidewater glaciers) and because the nearterminus hydrological system at tidewater glaciers will be continually pressurised as it meets the ocean tens to hundreds of metres below the surface. Theoretical considerations, initially motivated by surging glaciers, suggested that the transition between distributed and channelised drainage is sensitive to the basal sliding velocity $[61,71]$. The rapid motion, and thus likely basal sliding, at tidewater glaciers might therefore be expected to promote inefficient drainage and suppress efficient drainage relative to land-terminating margins.

Sole et al. [110] found transient seasonal acceleration and subsequent deceleration of ice flow in response to surface 
meltwater inputs to the bed at sites $>35 \mathrm{~km}$ inland from a tidewater glacier terminus in south-west Greenland, indicating parallels between land- and marine-terminating subglacial hydrology. For a number of stable tidewater glaciers in west Greenland, Howat et al. [111] reached similar conclusions based on remote sensing of ice velocity 4-6 km from their termini. In stark contrast, Sugiyama et al. [66] found a strong correlation between air temperature and ice velocity over two summers at lake-terminating Perito Moreno in Patagonia, indicative of a static hydrological system showing little seasonal evolution, and in which increases in surface melting consistently result in ice acceleration. At the ice sheet scale, Moon et al. [112] found evidence for both behaviours. It remains unclear what drives these differing seasonal patterns, and whether tidewater glaciers can exhibit spatial variability in seasonal evolution whereby the terminus behaves differently to locations further inland.

The importance of subglacial hydrology to tidewater glacier dynamics over longer timescales remains equivocal. Sustained, multiyear retreat typically drives a larger ice velocity response than that from surface melting alone $[86,113]$. Furthermore, inverse modelling suggests that basal friction beneath the trunks of three of Greenland's fastest flowing tidewater glaciers supports very little of the driving stress [114], such that the impact on ice dynamics of variability in basal friction due to surface melt input may be limited. However, subglacial hydrology may yet provide the perturbation necessary to drive a glacier into retreat; it has been inferred that surface melt-induced acceleration is responsible for significant dynamic thinning at Helheim Glacier [115], which has the potential to drive long-term glacier retreat if combined with a calving process dependent on ice terminus thickness [116].

Recent work has identified links between subglacial hydrology and ice-ocean interactions; the emergence of subglacial water at the grounding lines of tidewater glaciers plays a key role in drawing warm water along fjords to calving fronts [117] and in the transfer of heat from ocean to ice [118], with potential to promote terminus break-up. The near-terminus subglacial hydrology is also known to modulate the strength of fjord circulation [119] and submarine melting of the calving front [120]. The subglacial hydrology of tidewater glaciers is therefore likely to play a key part in Greenland's dynamic response to future climate warming, yet it remains very poorly understood.

\section{Key Unresolved Questions Regarding GrIS Hydrology}

While it is clear from the proliferation of published research over the last 15 years that considerable advances have been made regarding our understanding both of the hydrology of the Greenland ice sheet and its wider influences, there is much which remains uncertain and requires urgent attention. This section therefore summarises what we consider to be the key questions on which future research on GrIS hydrology should focus. Each brief summary is linked by number to Fig. 1 and moves sequentially through the hydrological system from surface meltwater source to the evacuation of meltwater from the ice sheet edge.

\section{Darkening of the Ice Sheet}

There is a pressing need to determine how the recent darkening of the ice sheet surface will evolve and thus how the associated changing albedo will impact surface mass balance $[19,121]$. This understanding is critical in order to improve model projections of future runoff from the ice sheet, which is the process that already dominates the GrIS's negative mass balance trend.

\section{Surface Firn Densification Processes}

Recent research has revealed dramatic increases in surface densification of the firn [29•], a decrease in water storage potential and the development of aquicludes [20], processes that promote enhanced meltwater runoff as opposed to refreezing and meltwater storage. Determining the spatiotemporal operation of these processes and the future trajectory of changes in firn structure is critical for improving future projections of ice sheet mass balance.

\section{Surface to Bed Connections at Higher Elevations}

The extent to which meltwater will penetrate to the bed at higher elevations has implications for the GrIS's future dynamic behaviour. The potential for ice bed connections to develop will depend on the bed to surface transfer of basal topography which controls the distribution and size of surface depressions and thus lakes [54] and on how surface melt and stress regimes, and thus crevasses, evolve [52•].

\section{Cryo-Hydrologic Warming}

The increased meltwater being generated at the ice sheet surface and draining subsequently into the ice has the potential to warm the ice that is in close proximity to water flowing through or filling moulins and crevasses [122] and being routed at the ice bed interface. It is unclear whether this increased meltwater will result in a significant rise in ice temperatures and thus deformation and flow rates [123], or will instead be of negligible importance to longer term ice dynamics [124]. 


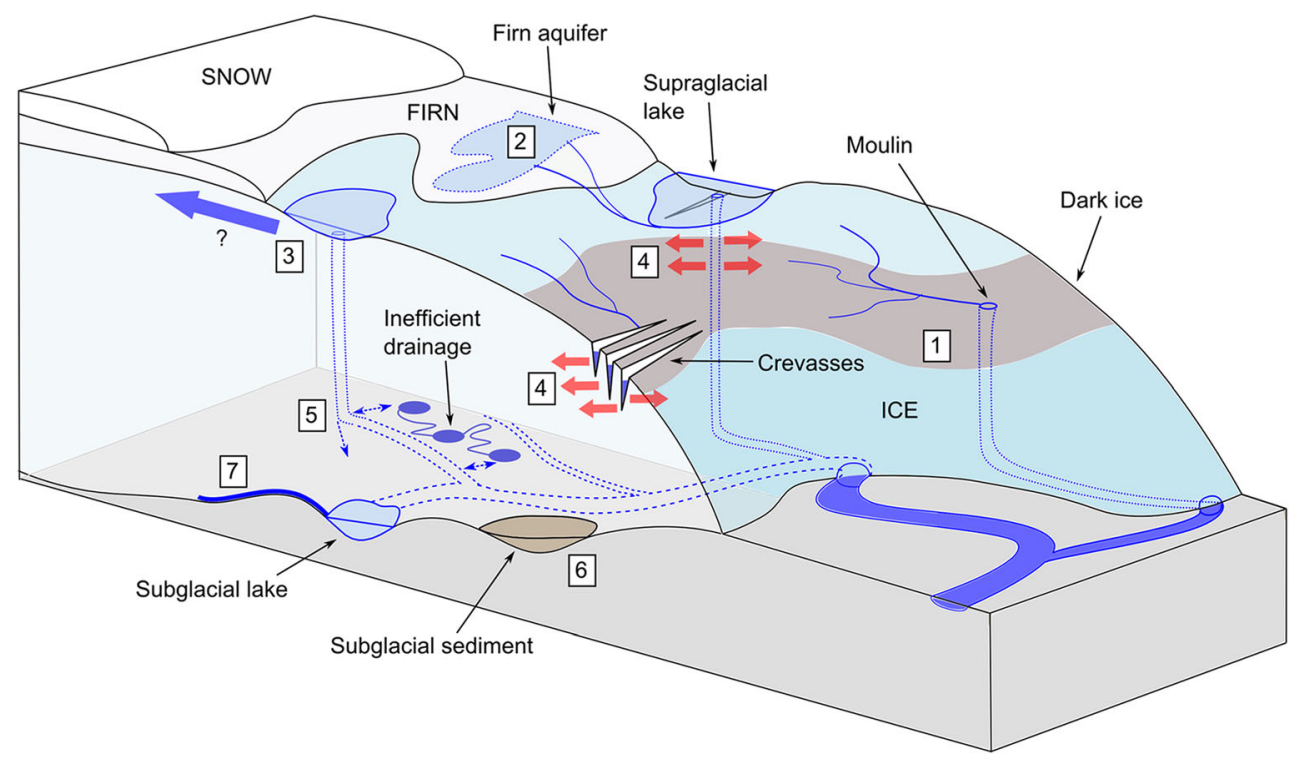

Fig. 1 A schematic illustration of a land-terminating section of the Greenland ice sheet, highlighting the main meltwater pathways and stores in the hydrological system. Critical areas of uncertainty regarding the future evolution of the hydrological system are numbered as discussed in the text: (1) darkening of the ice sheet, (2) surface firn densification processes, (3) surface to bed connections at higher elevations, (4) cryohydrologic warming, (5) rates of channelisation at the ice bed interface, (6) subglacial sediments and till deformation, and (7) basal melt rates. All of these processes are also relevant to tidewater glacier systems.

\section{Rates of Channelisation at the Ice Bed Interface}

The speed at which the subglacial drainage system evolves, following surface to bed connections via draining lakes and moulins, has implications for ice dynamics. Current contradictions between field data and modelling need to be resolved in order to improve the predictive capacity of fully coupled hydro-dynamic models.

\section{Subglacial Sediments and Till Deformation}

Recent surveys have reported the presence of subglacial till layers [73, 74]. The significance of such layers will depend on how extensive, thick and deformable they are and, if they are pervasive, how they will impact ice dynamics in a warming world driven by the enhanced subglacial runoff.

\section{Basal Melt Rates}

The magnitude and extent of basal melt occurring under the GrIS is poorly constrained [56]. Given the rapid flow of many tidewater glaciers, it is important to resolve whether the volume of meltwater generated by frictional heat is critical to their rapid ice motion [6] and if so, to better incorporate this process effectively in to predictive dynamic ice sheet models.

\section{Tidewater Glaciers}

The factors that control the complex dynamics of tidewater glaciers are numerous and the particular role that subglacial hydrology may play remains unclear [112]. Determining the extent to which enhanced meltwater will impact future tidewater glacier dynamics is critical for improving our understanding of the GrIS's dynamic contribution to sea level in a warming world.

\section{Discussion Regarding Future Priorities}

Current estimates suggest that since 1991, about $60 \%$ of the mass loss from the GrIS has been driven by surface mass balance [19], with the remainder due to calving and submarine ice melting. The likelihood of ongoing atmospheric warming [125] suggests that the processes that control surface mass balance will continue to dominate Greenland's mass balance signal [126], hence improving knowledge of meltwater processes 1 and 2 (Fig. 1) is critical. In tidewater systems, both surface mass balance and ice dynamics are important to mass loss and given that, since 2000 , between a third and a half of the Greenland ice sheet's annual mass loss has been driven by dynamic change at tidewater glaciers [24], an improved knowledge of the role of hydrology in tidewater glacier dynamics is needed. 
In land-terminating systems, we believe that dynamic changes driven by enhanced melt will likely be more limited for the following reasons. In order for a dramatic change in the ice dynamics of grounded land-terminating catchments, the ice sheet will need to accelerate substantially in response to rising meltwater inputs. For that to occur requires the maintenance of hydraulically inefficient subglacial drainage and thus a positive relationship between meltwater input and ice motion $[61,66]$. In contrast, the weight of evidence suggests a seasonal increase in drainage efficiency beneath the GrIS [62, 64] with no net acceleration on annual timescales [84, 87]. Furthermore if meltwater does continue to access the bed at increasingly high elevations (which may not be possible [52]), it will likely only be able to do so through the rapid drainage of large supraglacial lakes. We believe that the delivery of such large volumes of water will be capable of rapid channelisation, as is currently indicated by observations of lake drainage at lower elevations $[9,55,81]$, and that such channelisation will similarly result in only a limited or even negative net effect on annual ice velocity $[90 \bullet \bullet, 91]$. Cryo-hydraulic warming is also likely to have only a limited effect on rates of GrIS flow [124], not least due to the very limited spatial density of surface moulins and crevasses at high (>1000 m) elevations [51].

Further model development will be required to test these perspectives but the models first need to be able to better capture the current hydrological behaviour. For example, there is compelling evidence that efficient drainage develops rapidly, even at high elevations [55], following lake drainage. Current models by contrast $[65,69,73]$ typically require unrealistically long time scales to evolve large channels, as highlighted by Hoffman et al. [83•]. One possible issue is that these models start their incipient channel growth from very small channel dimensions, to represent an initial inefficient drainage system, which ensures that channel growth by frictional wall-melting is extremely slow. Channel formation could however be preconditioned by basal topography, the presence or otherwise of debris-laden basal ice [78] and permeable remnants of previous drainage systems [70, 83•]. In addition, following both initial lake and moulin drainage to the bed, there is often a substantial uplift of $\sim 0.1-1 \mathrm{~m}$ driven by ice bed separation $[9,41,55]$ suggesting that it may be more realistic for models, driven by surface inputs, to initiate channels with considerably larger dimensions.

\section{Conclusion}

The hydrology of the GrIS has come under increasing scrutiny in recent years. This reflects the recognition of both the dramatic increase in surface melt rates and that meltwaters can penetrate from the surface to the ice sheet bed through 'cold' ice $>1 \mathrm{~km}$ thick. Both processes have the potential to affect the mass balance of the ice sheet through increased surface runoff and enhanced ice motion with implications for ice mass loss and thus sea level. Furthermore, increased meltwater at the ice bed interface has implications for ice sheet erosion and the delivery of sediments and nutrients to downstream ecosystems.

The resulting impetus in research has revolutionised our understanding of GrIS hydrology. It is now clear that surface melt has increased dramatically, due to both increased air temperatures and the reduced albedo of the darkening ice sheet surface in the ablation zone. At higher elevations, the firn is becoming denser with less potential for meltwater storage by refreezing, and spatially extensive impermeable refrozen ice layers are forming which can route surface meltwater across the ice sheet surface towards the ablation zone. The net impact of these changes is an ice sheet surface with increasingly 'flashy' hydrology that can route meltwaters rapidly to crevasses, surface lakes and moulins from increasingly high elevations on the ice sheet.

Hydrofracture enables these surface waters to drain rapidly to the ice bed interface, often as a result of catastrophic lake drainage at high elevations (>1000 m). The subsequent connections have the ability to quickly develop efficient subglacial channels. As a result, since melt extends inland to increasingly higher elevations during the course of the melt season, the surface melt pattern drives the seasonal up glacier evolution of an efficient subglacial drainage system. Ice sheet motion is responsive, at a variety of temporal and spatial scales, to the delivery of large volumes of water from the surface to the ice bed interface. However, at the relatively well studied landterminating sectors of the ice sheet, the net impact of increasing melt on annual ice motion appears to be limited, even in areas inferred to be underlain by subglacial sediments. This reflects the ability of the drainage system to rapidly accommodate melt inputs, even in extreme melt years as in 2012, ensuring limited dynamic sensitivity to substantial interannual variations in surface melting. By contrast, the role of hydrology in affecting the rapid motion of marine-terminating glaciers remains unclear and must be better understood to improve predictions of the GrIS's future contribution to sea level.

The meltwaters draining from the ice sheet carry considerable volumes of sediment and solutes demonstrating extensive meltwater interactions at the ice bed interface, the efficacy of subglacial erosion processes and solute acquisition and the ability of the hydrological system to evacuate these products of erosion. The extent to which fluxes will change in response to projected increases in meltwater runoff are unclear, in large part due to the paucity of available data sets.

While considerable progress has been made, it is clear that many aspects of Greenland ice sheet hydrology, both in terms of the processes operating and their wider implications, remain unresolved (Fig. 1). The difficulties in observing ice sheet wide processes, and the subglacial domain in 
particular, and the short time over which most observations have been made ensure that our understanding of many aspects of the system remains embryonic. The increasing availability of vast volumes of satellite data provide invaluable opportunities to advance our understanding of the ice sheet system. Nevertheless, it remains clear that detailed observational field programmes, capable of obtaining data at unparalleled resolution and from otherwise inaccessible environments, are necessary to understand fully the ice sheet's hydrological system. These data need to be exploited in conjunction with the exciting ongoing advances in both remote sensing and numerical modelling in order to improve our predictions of how the GrIS will respond to future projections of climate change.

Acknowledgements We would like to thank the Section Editor, Tony Payne and Kristin Poinar and an anonymous referee for their detailed comments which improved the manuscript considerably.

Funding Nienow, Sole and Cowton's Greenland research has been supported by a number of UK NERC research grants (NER/O/S/2003/00620; NE/F021399/1; NE/H024964/1; NE/K015249/1; NE/K014609/1) and Slater has been supported by a NERC PhD studentship.

\section{Compliance with Ethical Standards}

Conflict of Interest On behalf of all authors, the corresponding author declares that there is no conflict of interest.

Human and Animal Rights and Informed Consent This article does not contain any studies with human or animal subjects performed by any of the authors.

Open Access This article is distributed under the terms of the Creative Commons Attribution 4.0 International License (http:// creativecommons.org/licenses/by/4.0/), which permits unrestricted use, distribution, and reproduction in any medium, provided you give appropriate credit to the original author(s) and the source, provide a link to the Creative Commons license, and indicate if changes were made.

\section{References}

Papers of particular interest, published recently, have been highlighted as:

- Of importance

•. Of major importance

1. Chu VW. Greenland ice sheet hydrology. Prog Phys Geogr. 2014;38(1):19-54. https://doi.org/10.1177/0309133313507075.

2. Fountain AG, Walder JS. Water flow through temperate glaciers. Rev Geophys. 1998;36(3):299-328. https://doi.org/10.1029/ 97RG03579.

3. Hooke RL. Englacial and subglacial hydrology: a qualitative review. Arct Alp Res. 1989;21(3):221-33. https://doi.org/10.2307/ 1551561.

4. Irvine-Fynn TDL, Hodson AJ, Moorman BJ, Vatne G, Hubbard AL. Polythermal glacier hydrology: a review. Rev Geophys. 2011;49:RG4002. https://doi.org/10.1029/2010RG000350.
5. Thomsen HH, Thorning L, Braithwaite RJ. Glacier hydrological conditions on the Inland Ice North-East of Jakobshavn/Illulisat, West Greenland. Grønlands Geologiske Undersøgelse 1988, Report 138.

6. Echelmeyer K, Clarke TS, Harrison WD. Surficial glaciology of Jakobshaven Isbrae, West Greenland: Part 1. Surface morphology. J Glaciol. 1991;37(127):368-82.

7. Joughin I, Tulaczyk S, Fahnestock M, Kwok R. A mini-surge on the Ryder Glacier, Greenland, observed by satellite radar interferometry. Science. 1996;274(5285):228-30. https://doi.org/10. 1126/science.274.5285.228.

8. Zwally HJ, Abdalati W, Herring T, Larson K, Saba J, Steffen K. Surface melt-induced acceleration of Greenland ice sheet flow. Science. 2002;297(5579):218-22. https://doi.org/10.1126/ science. 1072708.

9. Das SB, Joughin I, Behn MD, Howat IM, King MA, Lizarralde D, et al. Fracture propagation to the base of the Greenland ice sheet during supraglacial lake drainage. Science. 2008;320(5877):77881. https://doi.org/10.1126/science.1153360.

10. Greenwood SL, Clason CC, Helanow C, Margold M. Theoretical, contemporary observational and palaeo-perspectives on ice sheet hydrology: processes and products. Earth Sci Rev. 2016;155:127. https://doi.org/10.1016/j.earscirev.2016.01.010.

11. Flowers GE. Modelling water flow under glaciers and ice sheets. Proc R Soc Lond A: Math, Phys, Eng Sci. 2015;471:20140907. https://doi.org/10.1098/rspa.2014.0907.

12. Hall DK, Comiso JC, NE DG, Shuman CA, Box JE, Koenig LS. Variability in the surface temperature and melt extent of the Greenland ice sheet from MODIS. Geophys Res Lett. 2013;40(10):2114-20. https://doi.org/10.1002/grl.50240.

13. van As D, Hubbard AL, Hasholt B, Mikkelsen AB, van den Broeke MR, Fausto RS. Large surface meltwater discharge from the Kangerlussuaq sector of the Greenland ice sheet during the record-warm year 2010 explained by detailed energy balance observations. Cryosphere. 2012;6(1):199-209. https://doi.org/10. 5194/tc-6-199-2012.

14. Hanna E, Cropper TE, Hall RJ, Cappelen J. Greenland blocking index 1851-2015: a regional climate change signal. Int J Climatol. 2016;36(15):4847-61. https://doi.org/10.1002/joc.4673.

15. Box JE, Fettweis X, Stroeve JC, Tedesco M, Hall DK, Steffen K. Greenland ice sheet albedo feedback: thermodynamics and atmospheric drivers. Cryosphere. 2012;6(4):821-39. https://doi.org/10. 5194/tc-6-821-2012.

16. Wientjes IGM, Van de Wal RSW, Reichart GJ, Sluijs A, Oerlemans J. Dust from the dark region in the western ablation zone of the Greenland ice sheet. Cryosphere. 2011;5(3):589-601. https://doi.org/10.5194/tc-5-589-2011.

17. Bøggild CE, Brandt RE, Brown KJ, Warren SG. The ablation zone in northeast Greenland: ice types, albedos and impurities. J Glaciol. 2010;56(195):101-13. https://doi.org/10.3189/ 002214310791190776.

18. Chandler DM, Alcock JD, Wadham JL, Mackie SL, Telling J. Seasonal changes of ice surface characteristics and productivity in the ablation zone of the Greenland ice sheet. Cryosphere. 2015;9(2):487-504. https://doi.org/10.5194/tc-9-487-2015.

19. Charalampidis C, van As D, Box J, van den Broeke M, Colgan W, Doyle $S$, et al. Changing surface-atmosphere energy exchange and refreezing capacity of the lower accumulation area, West Greenland. Cryosphere. 2015;9(6):2163-81. https://doi.org/10. 5194/tc-9-2163-2015.

20. Mikkelsen A, Hubbard A, MacFerrin M, Box J, Doyle S, Fitzpatrick A, et al. Extraordinary runoff from the Greenland ice sheet in 2012 amplified by hypsometry and depleted firn-retention. Cryosphere. 2016;10:1147-59. https://doi.org/10.5194/tc10-1147-2016. 
21. Van Tricht K, Lhermitte S, Lenaerts J, Gorodetskaya I, Ecuyer T, Noël B, et al. Clouds enhance Greenland ice sheet meltwater runoff. Nat Comms. 2016;7 https://doi.org/10.1038/ncomms10266.

22. Hofer S, Tedstone A, Fettweis X, Bamber J. Decreasing cloud cover drives the recent mass loss on the Greenland ice sheet. Sci Adv. 2017;3(6):e1700584. https://doi.org/10.1126/sciadv. 1700584.

23. van den Broeke MR, Enderlin EM, Howat IM, Munneke PK, Noël BPY, van de Berg WJ, et al. On the recent contribution of the Greenland ice sheet to sea level change. Cryosphere. 2016;10: 1933-46. https://doi.org/10.5194/tc-10-1933-2016. This study provides an up to date estimate of the health of the GrIS and reveals that it is losing mass at an accelerating rate

24. Enderlin EM, Howat IM, Jeong S, Noh MJ, van Angelen JH, van den Broeke MR. An improved mass budget for the Greenland ice sheet. Geophys Res Lett. 2014;41(3):866-72. https://doi.org/10. 1002/2013GL059010.

25. Benson CS. Stratigraphic studies in the snow and firn of the Greenland ice sheet, research report 1962: 70, U.S. snow. Ice and Permafrost Research Establishment.

26. Jansson P, Hock R, Schneider T. The concept of glacier storage: a review. J Hydrol. 2003;282(1):116-29. https://doi.org/10.1016/ S0022-1694(03)00258-0.

27. Pfeffer WT, Meier MF, Illangasekare TH. Retention of Greenland runoff by refreezing: implications for projected future sea level change. J Geophys Res. 1991;96:22117-24.

28. Harper J, Humphrey N, Pfeffer WT, Brown J, Fettweis X. Greenland ice sheet contribution to sea-level rise buffered by meltwater storage in firn. Nature. 2012;491:240-3. https://doi. org/10.1038/nature11566.

29. Machguth H, MacFerrin M, van As D, Box JE, Charalampidis C, Colgan W, et al. Greenland meltwater storage in firn limited by near-surface ice formation. Nat Clim Chang. 2016;6:390-3. https://oi.org/10.1038/nclimate2899. This study of the firn reveals a decrease in the potential for the storage of meltwaters, due to firn densification and the formation of extensive near-surface ice layers, thereby causing meltwaters to drain rapidly over the ice sheet surface rather than to percolate and refreeze within the firn.

30.• Forster RR, Box JE, van den Broeke MR, Miege C, Burgess EW, van Angelen JH, et al. Extensive liquid meltwater storage in firn within the Greenland ice sheet. Nat Geos. 2014;7:95-8. https:// doi.org/10.1038/ngeo2043. This paper shows that a substantial amount of water is stored in the firn in a liquid aquifer and that it persists throughout the winter; this represents a previously unknown storage mode for water within the ice sheet.

31. Miege C, Forster RR, Brucker L, Koenig LS, Solomon DK, Paden JD, et al. Spatial extent and temporal variability of Greenland firn aquifers detected by ground and airborne radars. J Geophys Res: Earth Surf. 2016;121(12):2381-98. https://doi.org/10.1002/ 2016JF003869.

32. Poinar K, Joughin I, Lilien D, Brucker L, Kehrl L, Nowicki S. Drainage of southeast Greenland firn aquifer water through crevasses to the bed. Front Earth Sci. 2017;5:5. https://doi.org/10. 3389/feart.2017.00005.

33. Holmes GW. Morphology and hydrology of the Mint Julep area, Southwest Greenland. Mint Julep Reports, Part II, 1955. Arctic Desert Topic Information Center U.S. Air University: Pub. A-104B.

34. Nienow P, Hubbard B. Surface and Englacial drainage of glaciers and ice sheets. In: Anderson MG, editor. Encyclopedia of Hydrological Sciences. John Wiley and Sons, Ltd; 2005. https:// doi.org/10.1002/0470848944.hsa172.
35. Selmes N, Murray T, James TD. Fast draining lakes on the Greenland ice sheet. Geophys Res Lett. 2011;38:L15501. https:// doi.org/10.1029/2011GL047872.

36. Gudmundsson GH. Transmission of basal variability to a glacier surface. J Geophys Res: Solid Earth. 2003;108(B5):2253. https:// doi.org/10.1029/2002JB002107.

37. Sergienko OV. Glaciological twins: basally controlled subglacial and supraglacial lakes. J Glaciol. 2013;59(213):3-8. https://doi. org/10.3189/2013JoG12J040.

38. Fitzpatrick AAW, Hubbard AL, Box JE, Quincey DJ, van As D, Mikkelsen APB, et al. A decade (2002-2012) of supraglacial lake volume estimates across Russell Glacier, West Greenland. Cryosphere. 2014;8(1):107-21. https://doi.org/10.5194/tc-8-1072014.

39. Leeson AA, Shepherd A, Briggs K, Howat I, Fettweis X, Morlighem M, et al. Supraglacial lakes on the Greenland ice sheet advance inland under warming climate. Nat Clim Chang. 2015;5: 51-5. https://doi.org/10.1038/nclimate2463.

40. Sundal A, Shepherd A, Nienow P, Hanna E, Palmer S, Huybrechts P. Evolution of supra-glacial lakes across the Greenland ice sheet. Remote Sens Environ. 2009;113(10):2164-71. https://doi.org/10. 1016/j.rse.2009.05.018.

41. Doyle SH, Hubbard AL, Dow CF, Jones GA, Fitzpatrick A, Gusmeroli A, et al. Ice tectonic deformation during the rapid in situ drainage of a supraglacial lake on the Greenland ice sheet. Cryosphere. 2013;7(1):129-40. https://doi.org/10.5194/tc-7-1292013.

42. Krawczynski MJ, Behn MD, Das SB, Joughin I. Constraints on the lake volume required for hydro-fracture through ice sheets. Geophys Res Lett. 2009;36:L10501. https://doi.org/10.1029/ 2008GL036765.

43. Kingslake J, Ng F, Sole A. Modelling channelized surface drainage of supraglacial lakes. J Glaciol. 2015;61(225):185-99. https:// doi.org/10.3189/2015JoG14J158.

44. Koziol C, Arnold N, Pope A, Colgan W. Quantifying supraglacial meltwater pathways in the Paakitsoq region, west Greenland. J Glaciol. 2017;63(239):464-76. https://doi.org/10.1017/jog.2017. 5 .

45. Tedesco M, Willis IC, Hoffman MJ, Banwell AF, Alexander P, Arnold NS. Ice dynamic response to two modes of surface lake drainage on the Greenland ice sheet. Environ Res Lett. 2013;8. https://doi.org/10.1088/1748-9326/8/3/034007.

46. Clason CC, DWF M, Nienow PW, Bartholomew ID, Sole A, Palmer S, et al. Modelling the transfer of supraglacial meltwater to the bed of Leverett Glacier, Southwest Greenland. Cryosphere. 2015;9(1):123-38. https://doi.org/10.5194/tc-9-123-2015.

47. Stevens LA, Behn MD, McGuire JJ, Das SB, Joughin I, Herring T, Shean DE, King MA. Greenland supraglacial lake drainages triggered by hydrologically induced basal slip. Nature. 2015;522. https://doi.org/10.1038/nature14480.

48. van der Veen CJ. Fracture propagation as means of rapidly transferring surface meltwater to the base of glaciers. Geophys Res Lett. 2007;34. https://doi.org/10.1029/2006GL028385.

49. Smith LC, Chu VW, Yang K, Gleason CJ, Pitcher LH, Rennermalm AK, et al. Efficient meltwater drainage through supraglacial streams and rivers on the Southwest Greenland ice sheet. Proc Natl Acad Sci. 2015;112(4):1001-6. https://doi.org/ 10.1073/pnas. 1413024112 .

50. Catania GA, Neumann TA. Persistent englacial drainage features in the Greenland ice sheet. Geophys Res Lett. 2010;37 https://doi. org/10.1029/2009GL041108.

51. Phillips T, Leyk S, Rajaram H, Colgan W, Abdalati W, McGrath $\mathrm{D}$, et al. Modeling moulin distribution on Sermeq Avannarleq glacier using ASTER and WorldView imagery and fuzzy set theory. Remote Sens Environ. 2011;115(9):2292-301. https://doi. org/10.1016/j.rse.2011.04.029. 
52. Poinar K, Joughin I, Das SB, Behn MD, JTM L, van den Broeke MR. Limits to future expansion of surface-melt-enhanced ice flow into the interior of western Greenland. Geophys Res Lett. 2015;42(6):1800-7. https://doi.org/10.1002/2015GL063192.

This paper investigates surface strain rates in conjunction with a thermal model and suggests that in a warming climate, new supraglacial lakes at higher elevation will have a limited effect on the inland expansion of hydro-dynamic coupling because the surface meltwaters will be unable to access the ice bed interface.

53. Howat IM, de la Pena S, van Angelen JH, Lenaerts JTM, van den Broeke MR. Expansion of meltwater lakes on the Greenland ice sheet. Cryosphere. 2013;7(1):201-4. https://doi.org/10.5194/tc-7201-2013.

54. Igneczi A, Sole AJ, Livingstone SJ, Leeson AA, Fettweis X, Selmes N, et al. Northeast sector of the Greenland ice sheet to undergo the greatest inland expansion of supraglacial lakes during the 21st century. Geophys Res Lett. 2016;43(18):9729-38. https:// doi.org/10.1002/2016GL070338.

55. Bartholomew I, Nienow P, Sole A, Mair D, Cowton T, King MA. Short-term variability in Greenland ice sheet motion forced by time-varying meltwater drainage: Implications for the relationship between subglacial drainage system behavior and ice velocity. J Geophys Res: Earth Surf. 2012;117:F03002. https://doi.org/10. 1029/2011JF002220

56. JA MG, Fahnestock MA, Catania GA, Aschwanden A, Clow GD, Colgan WT, et al. A synthesis of the basal thermal state of the Greenland ice sheet. J Geophys Res: Earth Surf. 2016;121(7): 1328-50. https://doi.org/10.1002/2015JF003803.

57. Seroussi H, Morlighem M, Rignot E, Khazendar A, Larour E, Mouginot J. Dependence of century-scale projections of the Greenland ice sheet on its thermal regime. J Glaciol. 2013;59(218):1024-34. https://doi.org/10.3189/2013JoG13J054.

58.• Andrews LC, Catania GA, Hoffman MJ, Gulley JD, Luthi MP, Ryser C, et al. Direct observations of evolving subglacial drainage beneath the Greenland ice sheet. Nature. 2014;514:80-3. https:// doi.org/10.1038/nature13796. This study monitors the subglacial water pressure using both boreholes and moulins in order to understand how changes in the pressure in different parts of the subglacial drainage system ultimately control ice dynamics.

59. Hubbard BP, Sharp MJ, Willis IC, Nielsen MK, Smart CC. Borehole water-level variations and the structure of the subglacial hydrological system of Haut Glacier d'Arolla, Valais. Switzerland J Glaciol. 1995;41(139):572-83.

60. Palmer SJ, Dowdeswell JA, Christoffersen P, Young DA, Blankenship DD, Greenbaum JS, et al. Greenland subglacial lakes detected by radar. Geophys Res Lett. 2013;40(23):6154-9. https:// doi.org/10.1002/2013GL058383.

61. Kamb B. Glacier surge mechanism based on linked cavity configuration of the basal water conduit system. J Geophys Res. 1987;92(B9):9083-100. https://doi.org/10.1029/ JB092iB09p09083.

62. Chandler DM, Wadham JL, Lis GP, Cowton T, Sole A, Bartholomew I, et al. Evolution of the subglacial drainage system beneath the Greenland ice sheet revealed by tracers. Nat Geosci. 2013;6:195-8. https://doi.org/10.1038/ngeo1737.

63. Cowton T, Nienow P, Sole A, Wadham J, Lis G, Bartholomew I, et al. Evolution of drainage system morphology at a landterminating Greenlandic outlet glacier. J Geophys Res Earth Surf. 2013;118(1):29-41. https://doi.org/10.1029/2012JF002540.

64. Bartholomew I, Nienow P, Sole A, Mair D, Cowton T, Palmer S, et al. Supraglacial forcing of subglacial drainage in the ablation zone of the Greenland ice sheet. Geophys Res Lett. 2011;38. https://doi.org/10.1029/2011GL047063.
65. Dow CF, Kulessa B, Rutt IC, Doyle SH, Hubbard A. Upper bounds on subglacial channel development for interior regions of the Greenland ice sheet. J Glaciol. 2014;60:1044-52. https:// doi.org/10.3189/2014JoG14J093.

66. Sugiyama S, Skvarca P, Nozomu NN, Enomoto H, Tsutaki S, et al. Ice speed of a calving glacier modulated by small fluctuations in basal water pressure. Nat Geosci. 2011;5:597-600. https://doi.org/ 10.1038/ngeo1218.

67. Dow C, Kulessa B, Rutt I, Tsai V, Pimentel S, Doyle S, et al. Modeling of subglacial hydrological development following rapid supraglacial lake drainage. J Geophys Res: Earth Surface. 2015;120:1127-47 https://doi.org/10.1002/2014JF003333.

68. Gordon S, Sharp M, Hubbard B, Smart C, Ketterling B, Willis I. Seasonal reorganization of subglacial drainage inferred from measurements in boreholes. Hydrol Process. 1998;12(1):105-33. https://doi.org/10.1002/(SICI)1099-1085(199801)12:1<105:: AID-HYP566>3.0.CO;2-

69. Meierbachtol T, Harper J, Humphrey N. Basal Drainage System Response to Increasing Surface Melt on the Greenland Ice Sheet. Science. 2013;34:777. https://doi.org/10.1126/science.1235905.

70. Hewitt IJ. Seasonal changes in ice sheet motion due to melt water lubrication. Earth Planet Sci Lett. 2013;371:16-25. https://doi.org/ 10.1016/j.epsl.2013.04.022.

71. Schoof C. Ice sheet acceleration driven by melt supply variability. Nature. 2010;468:803-6. https://doi.org/10.1038/nature09618.

72. Werder MA, Hewitt IJ, Schoof CG, Flowers GE. Modeling channelized and distributed subglacial drainage in two dimensions. J Geophys Res Earth Surf. 2013;118(4):2140-58. https://doi.org/ 10.1002/jgrf.20146.

73. Dow CF, Hubbard A, Booth AD, Doyle SH, Gusmeroli A, Kulessa B. Seismic evidence of mechanically weak sediments underlying Russell Glacier, west Greenland. Ann Glaciol. 2013;54:135-41. https://doi.org/10.3189/2013AoG64A03.

74. Walter F, Chaput J, Luthi MP. Thick sediments beneath Greenland's ablation zone and their potential role in future ice sheet dynamics. Geol. 2014;42(6):487. https://doi.org/10.1130/ G35492.1.

75. Kulessa B, Hubbard AL, Booth AD, Bougamont M, Dow CF, Doyle $\mathrm{SH}$, et al. Seismic evidence for complex sedimentary control of Greenland ice sheet flow. Sci Adv. 2017;3:e1603071 https://doi.org/10.1126/sciadv.1603071.

76. Bougamont M, Christoffersen P, Hubbard AL, Fitzpatrick AA, Doyle SH, Carter SP. Sensitive response of the Greenland ice sheet to surface melt drainage over a soft bed. Nat Comms. 2014;5 https://doi.org/10.1038/ncomms6052.

77. Jezek K, Wu X, Paden J, Leuschen C. Radar mapping of Isunnguata Sermia, Greenland. J Glac. 2013;59(218):1135-46. https://doi.org/10.3189/2013JoG12J248

78. Harper JT, Humphrey NF, Meierbachtol TW, Graly JA, Fischer $\mathrm{UH}$. Borehole measurements indicate hard bed conditions, Kangerlussuaq sector, western Greenland ice sheet. J Geophys Res:Earth Surf. 2017;122 https://doi.org/10.1002/2017JF004201.

79. van de Wal RSW, Boot W, van den Broeke MR, Smeets CJPP, Reijmer $\mathrm{CH}$, Donker JJA, et al. Large and rapid melt-induced velocity changes in the ablation zone of the Greenland ice sheet. Science. 2008;321(5885):111-3. https://doi.org/10.1126/science. 1158540.

80. Bartholomew I, Nienow P, Mair D, Hubbard A, King MA, Sole A. Seasonal evolution of subglacial drainage and acceleration in a Greenland outlet glacier. Nat Geosci. 2010;3:408-11. https://doi. org/10.1038/ngeo863.

81. Hoffman MJ, Catania GA, Neumann TA, Andrews LC, Rumrill JA. Links between acceleration, melting, and supraglacial lake drainage of the western Greenland ice sheet. J Geophys Res Earth Surf. 2011;116 (F4) https://doi.org/10.1029/2010JF001934. 
82. Cowton T, Nienow P, Sole A, Bartholomew I, Mair D. Variability in ice motion at a land-terminating Greenlandic outlet glacier: the role of channelized and distributed drainage systems. J Glaciol. 2016;62(233):451-66. https://doi.org/10.1017/jog.2016.36.

83. Hoffman MJ, Andrews LC. Price SA, Catania, GA, Neumann, TA, Lüthi MP, et al. Greenland subglacial drainage evolution regulated by weakly connected regions of the bed. Nat Comms. 2016;7:13903. https://doi.org/10.1038/ncomms13903. This study uses numerical modelling to enhance understanding of the complex hydraulic connections between different areas of the subglacial drainage system.

84. Tedstone AJ, Nienow PW, Sole AJ, Mair DWF, Cowton TR, Bartholomew ID, et al. Greenland ice sheet motion insensitive to exceptional meltwater forcing. Proc Natl Acad Sci. 2013;110(49): 19719-24. https://doi.org/10.1073/pnas.1315843110.

85. Doyle SH, Hubbard A, van de Wal RSW, Box JE, van As D, Scharrer K, et al. Amplified melt and flow of the Greenland ice sheet driven by late-summer cyclonic rainfall. Nat Geos. 2015;8: 647-53. https://doi.org/10.1038/ngeo2482.

86. Joughin I, Das S, King MA, Smith B, Howat I, Moon T. Seasonal speedup along the western flank of the Greenland ice sheet. Science. 2008;320(5877):781-3. https://doi.org/10.1126/science. 1153288.

87. Sole A, Nienow P, Bartholomew I, Mair D, Cowton T, Tedstone A, et al. Winter motion mediates dynamic response of the Greenland ice sheet to warmer summers. Geophys Res Lett. 2013;40(15):3940-4. https://doi.org/10.1002/grl.50764.

88. Stevens LA, Behn MD, Das SB, Joughin I, BPY N, van den Broeke MR, et al. Greenland ice sheet flow response to runoff variability. Geophys Res Lett. 2016;43(21):11295-303. https:// doi.org/10.1002/2016GL070414. This study uses a detailed network of ice velocity measurements over an 8-year period to reveal a clear decrease in rates of annual ice motion along a land-terminating sector of the GrIS.

89. Sundal AV, Shepherd A, Nienow P, Hanna E, Palmer S, Huybrechts P. Melt-induced speed-up of Greenland ice sheet offset by efficient subglacial drainage. Nature. 2011;469:521-4. https://doi.org/10.1038/nature09740.

90.• Tedstone AJ, Nienow PW, Gourmelen N, Dehecq A, Goldberg D, Hanna E. Decadal slowdown of a land-terminating sector of the Greenland ice sheet despite warming. Nature. 2015;526(7575): 692-5. https://doi.org/10.1038/nature15722. This study uses remotely sensed data of ice motion over an $8000-\mathrm{km}^{2}$ margin of the GrIS in conjunction with surface melt-modelling to reveal a clear decadal slowdown of a land-terminating sector of the Greenland ice sheet despite pronounced warming.

91. van de Wal RSW, Smeets CJPP, Boot W, Stoffelen M, van Kampen R, Doyle SH, et al. Self-regulation of ice flow varies across the ablation area in south-west Greenland. Cryosphere. 2015;9(2):603-11. https://doi.org/10.5194/tc-9-603-2015.

92. Doyle SH, Hubbard A, Fitzpatrick AAW, van As D, Mikkelsen $\mathrm{AB}$, Pettersson R, et al. Persistent flow acceleration within the interior of the Greenland ice sheet. Geophys Res Lett. 2014;41(3):899-905. https://doi.org/10.1002/2013GL058933.

93. Shannon S, Payne A, Bartholomew I, van den Broeke M, Edwards T, Fettweis X, et al. Enhanced basal lubrication and the contribution of the Greenland ice sheet to future sea-level rise. Proc Natl Acad Sci. 2013; https://doi.org/10.1073/pnas.1212647110.

94. Hallet B, Hunter L, Bogen J. Rates of erosion and sediment evacuation by glaciers: a review of field data and their implications. Glob Planet Chang. 1996;12(1):213-35. https://doi.org/10.1016/ 0921-8181(95)00021-6.

95. Andrews JT, Milliman JD, Jennings AE, Rynes N, Dwyer J. Sediment thicknesses and Holocene glacial marine sedimentation rates in three east Greenland fjords (ca. $\left.68^{\circ} \mathrm{N}\right)$. J Geol. 1994;102(6):669-83. https://doi.org/10.1086/629711.
96. Cowton T, Nienow P, Bartholomew I, Sole A, Mair D. Rapid erosion beneath the Greenland ice sheet. Geol. 2012;40(4):3436. https://doi.org/10.1130/G32687.1.

97. Young NE, Briner JP, Maurer J, Schaefer JM. ${ }^{10}$ Be measurements in bedrock constrain erosion beneath the Greenland ice sheet margin. Geophys. Res. Lett. 2016;43:11,708-19. https://doi.org/10. 1002/2016GL070258.

98. Hasholt B, Mikkelsen AB, Nielsen MH, Larsen MAD. Observations of runoff and sediment and dissolved loads from the Greenland ice sheet at Kangerlussuaq, west Greenland, 2007 to 2010. Zeitschrift fur Geomorphologie, Supplementary Issues. 2013;57(2):3-27. https://doi.org/10.1127/0372-8854/2012/S00121.

99. Garde AA. 181, edited by F. Copenhagen: Kalsbeek; Steenfelt A. Precambrian geology of Nuussuaq and the area north-east of Disko Island, In Precambrian geology of the Disko Bugt region, west Greenland, in Geology of Greenland Survey Bulletin, 1999.

100. Hudson B, Overeem I, McGrath D, Syvitski JPM, Mikkelsen A, Hasholt B. MODIS observed increase in duration and spatial extent of sediment plumes in Greenland fjords. Cryosphere. 2014;8(4):1161-76. https://doi.org/10.5194/tc-8-1161-2014.

101. Bhatia MP, Kujawinski EB, Das SB, Breier CF, Henderson PB, Charette MA. Greenland meltwater as a significant and potentially bioavailable source of iron to the ocean. Nat Geosci. 2013;6:274 8. https://doi.org/10.1038/ngeo1746.

102. Graly JA, Humphrey NF, Landowski CM, Harper JT. Chemical weathering under the Greenland ice sheet. Geology. 2014;42(6): 551-4. https://doi.org/10.1130/G35370.1.

103. Hawkings JR, Wadham JL, Tranter M, Lawson E, Sole A, Cowton $\mathrm{T}$, et al. The effect of warming climate on nutrient and solute export from the Greenland ice sheet. Geochem Perspect Lett. 2015;1(1):94-104. https://doi.org/10.7185/geochemlet.1510. This paper uses measurements of solutes in glacial runoff to suggest that the GrIS will in the future provide substantial quantities of nutrients to the ocean's surrounding Greenland with potential to impact marine primary productivity.

104. Yde JC, Knudsen T, Hasholt B, Mikkelsen AB. Meltwater chemistry and solute export from a Greenland ice sheet catchment, Watson River, West Greenland. J Hydrol. 2014;519:2165-79. https://doi.org/10.1016/j.jhydrol.2014.10.018.

105. Meire L, Meire P, Struyf E, Krawczyk DW, Arendt KE, Yde JC, et al. High export of dissolved silica from the Greenland ice sheet. Geophys Res Lett. 2016;43:9173-82. https://doi.org/10.1002/ 2015JG003240.

106. Hopwood MJ, Connelly DP, Arendt KE, Juul-Pedersen T, Stinchcombe MC, Meire L, et al. Seasonal changes in Fe along a glaciated Greenlandic fjord. Frontiers in Earth Science. 2016;4: 15. https://doi.org/10.3389/feart.2016.00015.

107. Joughin I, Howat I, Alley RB, Ekstrom G, Fahnestock M, Moon $\mathrm{T}$, et al. Ice-front variation and tidewater behavior on Helheim and Kangerdlugssuaq glaciers, Greenland. J Geophys Res: Earth Surf. 2008;113:F01004. https://doi.org/10.1029/2007JF000837.

108. Moon T, Joughin I, Smith B. Seasonal to multi-year variability of glacier surface velocity, terminus position, and sea ice/ice melange in northwest Greenland. J Geophys Res: Earth Surf. 2015;120(5): 818-33. https://doi.org/10.1002/2015JF003494.

109. Voytenko D, Stern A, Holland DM, Dixon TH, Christianson K, Walker RT. Tidally driven ice speed variation at Helheim Glacier, Greenland, observed with terrestrial radar interferometry. J Glaciol. 2015;61(226):301-8. https://doi.org/10.3189/ 2015JoG14J173.

110. Sole AJ, Mair DWF, Nienow PW, Bartholomew ID, King MA, Burke MJ, et al. Seasonal speedup of a Greenland marineterminating outlet glacier forced by surface melt induced changes in subglacial hydrology. J Geophys Res Earth Surf. 2011;116: F03014. https://doi.org/10.1029/2010JF001948. 
111. Howat IM, Box JE, Ahn Y, Herrington A, McFadden EM. Seasonal variability in the dynamics of marine-terminating outlet glaciers in Greenland. J Glaciol. 2010;56(198):601-13. https:// doi.org/10.3189/002214310793146232.

112. Moon T, Joughin I, Smith B, van den Broeke MR, van de Berg WJ, Noel B, et al. Distinct patterns of seasonal Greenland glacier velocity. Geophys Res Lett. 2014;41(20):7209-16. https://doi.org/ 10.1002/2014GL061836.

113. Nick FM, Vieli A, Howat IM, Joughin I. Large-scale changes in Greenland outlet glacier dynamics triggered at the terminus. Nat Geos. 2009;2(2):110-4. https://doi.org/10.1038/ngeo394.

114. Shapero DR, Joughin IR, Poinar K, Morlighem M, Gillet-Chaulet F. Basal resistance for three of the largest Greenland outlet glaciers. J Geophys Res: Earth Surf. 2016;121(1):168-80. https://doi. org/10.1002/2015JF003643.

115. Bevan SL, Luckman A, Khan SA, Murray T. Seasonal dynamic thinning at Helheim Glacier. Earth Planet Sci Lett. 2015;415:4753. https://doi.org/10.1016/j.eps1.2015.01.031.

116. James TD, Murray T, Selmes N, Scharrer K, O'Leary M. Buoyant flexure and basal crevassing in dynamic mass loss at Helheim Glacier. Nat Geosci. 2014;7:593-6. https://doi.org/10.1038/ ngeo2204.

117. Straneo F, Curry RG, Sutherland DA, Hamilton GS, Cenedese C, Vage $\mathrm{K}$, et al. Impact of fjord dynamics and glacial runoff on the circulation near Helheim Glacier. Nat Geos. 2011;4(5):322-7. https://doi.org/10.1038/ngeo1109.

118. Motyka RJ, Hunter L, Echelmeyer KA, Connor C. Submarine melting at the terminus of a temperate tidewater glacier, Leconte Glacier, Alaska, USA. Ann Glaciol. 2003;36(1):57-65. https:// doi.org/10.3189/172756403781816374.

119. Carroll D, Sutherland DA, Shroyer EL, Nash JD, Catania GA, Stearns LA. Modeling turbulent subglacial meltwater plumes: implications for fjord-scale buoyancy-driven circulation. J Phys Oceanogr. 2015;45(8):2169-85. https://doi.org/10.1175/JPO-D15-0033.1.

120. Slater DA, Nienow PW, Cowton TR, Goldberg DN, Sole AJ. Effect of near-terminus subglacial hydrology on tidewater glacier submarine melt rates. Geophys Res Lett. 2015;42(8):2861-8. https://oi.org/10.1002/2014GL062494.

121. Tedesco M, Doherty S, Fettweis X, Alexander P, Jeyaratnam J, Stroeve J. The darkening of the Greenland ice sheet: trends, drivers, and projections (1981-2100). Cryosphere. 2016;10(2): 477-96. https://doi.org/10.5194/tc-10-477-2016.

122. Lüthi MP, Ryser C, Andrews LC, Catania GA, Funk M, Hawley RL, et al. Heat sources within the Greenland ice sheet: dissipation, temperate paleo-firn and cryo-hydrologic warming. Cryosphere. 2015;9(1):245-53. https://doi.org/10.5194/tc-9-245-2015.

123. Phillips T, Rajaram H, Steffen K. Cryo-hydrologic warming: a potential mechanism for rapid thermal response of ice sheets. Geophys Res Lett. 2010;37:L20503. https://doi.org/10.1029/ 2010 GL044397.

124. Poinar K, Joughin I, Lenaerts JTM, van den Broeke MR. Englacial latent-heat transfer has limited influence on seaward ice flux in western Greenland. J Glaciol. 2016; https://doi.org/10.1017/jog. 2016.103.

125. Fyke J, Matthews HD. A probabilistic analysis of cumulative carbon emissions and long-term planetary warming. Environ Res Lett. 2015;10(11):115,007.

126. Fettweis X, Franco B, Tedesco M, van Angelen JH, Lenaerts JTM, van den Broeke MR, et al. Estimating the Greenland ice sheet surface mass balance contribution to future sea level rise using the regional atmospheric climate model MAR. Cryosphere. 2013;7(2):469-89. https://doi.org/10.5194/tc-7-469-2013. 